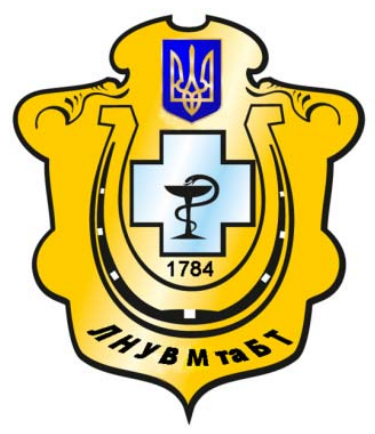

Науковий вісник Львівського національного університету ветеринарної медицини та біотехнологій імені С.3. Гжицького

Scientific Messenger of Lviv National University of Veterinary Medicine and Biotechnologies named after S.Z. Gzhytskyj

doi:10.15421/nvlvet6908

ISSN 2413-5550 print

ISSN 2518-1327 online

http://nvlvet.com.ua/

УДК 631.1.:637.1

\title{
Розвиток молочного скотарства Львівщини
}

\author{
В.Л. Диндин \\ Dyndynmisha@mail.ru \\ Львівський національний університет ветеринарної медицини та біотехнологій імені С.3. Гжицького, \\ вул. Пекарська, 50, м. Львів, 79010, Украӥна
}

\begin{abstract}
Сільське господарство, як окрема галузь народного господарства є однією із пріоритетних і важливих сфер діяльності будь-якої держави. Від характеру ї̈ розвитку безперечно залежить продовольча безпека країни і характер показників національної економіки зокрема. Адже, головним економічним призначенням будь-якого господарського формування, що $\epsilon$ невід'ємною складовою иілісної системи галузі забезпечення життєвонеобхідними продуктами харчування населення краӥни в їх необхідній кількості, створення робочих місиь щзо, як наслідок, веде до покращення показників зайнятості, формування розвиненої ринкової інфраструктури (виробництво, заготівля, переробка, реалізація сільськогосподарської продукuіiі). Однією з провідних ланок сільського господарства є молокопродуктовий підкомплекс, зокрема молочне скотарство. Основною метою галузі молочного скотарства є виробництво в необхідній кількості молока і молочних продуктів. Особливості молока, як харчового продукту зумовлені його хімічним складом і властивостями окремих компонентів, які забезпечують високу біологічну иінність. Молоко - це унікальний продовольчий продукт, який досі не синтезований у світі. За складом з ним не може конкурувати жоден із харчових продуктів.

Нажаль, в сьогоднішніх умовах, дана місія не зовсім виконується більшістю господарюючих суб'єктів Львівщини. Проблеми, щуо існують в галузі практично набули системного характеру, вирішення яких потребує комплексного підходу. Результатами нашої роботи є дослідження характеру розвитку молочного скотарства в області та виявлення причин, що гальмують розвиток галузі.
\end{abstract}

Ключові слова: ефективність, сільське господарство, молочне скотарство, поголів'я корів, продуктивність корів, системний підхід.

\section{Развития молочного скотоводства Львовщины}

\author{
В.Л. Дындын \\ Dyndynmisha@mail.ru
}

\begin{abstract}
Львовский национальный университет ветеринарной медицины и биотехнологий имени С.3. Гжицкого, ул. Пекарская, 50, г. Львов, 79010, Украина
\end{abstract}

Сельское хозяйство как отдельная отрасль народного хозяйства является одной из приоритетных и важных сфер деятельности любого государства. От характера ее развития бесспорно зависит продовольственная безопасность страны и характер показателей начиональной экономики в частности. Ведь, главным экономическим назначением любого хозяйственного формирования, что является неотъемлемой составляющей целостной системы отрасли обеспечение життєвонеобхіднми продуктами питания населения страны в их необходимом количестве, создание рабочих мест, как следствие, ведет к улучшению показателей занятости, формирование развитой рыночной инфраструктуры (производство, заготовка, переработка, реализачия сельскохозяйственной продукичи). Одним из ведущих звеньев сельского хозяйства является молокопродуктовий подкомплекс, в частности молочное скотоводство. Основной челью отрасли молочного скотоводства является производство в необходимом количестве молока и молочных продуктов. Особенности молока, как пищевого продукта обусловлены его химическим составом и свойствами отдельных компонентов, которые обеспечивают высокую биологическую иенность. Молоко это уникальный продовольственный продукт, который до сих пор не синтезирован в мире. По составу с ним не может конкурировать ни один из пищевых продуктов.

Citation:

Dundun, V.L. (2016). Development of suckling cattle breeding of Lvov. Scientific Messenger LNUVMBT named after S.Z. Gzhytskyj, 18, 2(69), 4852. 
К сожалению, в сегодняшних условиях, данная миссия не совсем выполняется большинством хозяйствующих субъектов Львовщчны. Проблемы, существующие в отрасли практически приобрели системного характера, рещение которых требует комплексного подхода. Результатами нашей работы является исследование характера развития молочного скотоводства в области и выявление причин, тормозящчи развитие отрасли.

Ключевые слова: эффективность, сельское хазяйство, молочное скотоводство, поголовье коров, продуктивность коров, системный подход.

\title{
Development of suckling cattle breeding of Lviv
}

\author{
V.L. Dyndyn \\ Dyndynmisha@mail.ru \\ Lviv National University of Veterinary Medicine and Biotechnologies named after S.Z. Gzhytskyi, \\ Pekarska Str., 50, Lviv, 79010, Ukraine
}

\begin{abstract}
Agriculture as a separate sector of the economy is a priority and important areas of any state. The nature of its development undoubtedly depends the food security of the country and the nature of the indicators of the national economy in particular. After all, the main economic purpose of any economic formation that is an integral part of the holistic system of the industry providing rotten food of the population in their required amount, the creation of jobs, as a consequence, leads to improved employment, the formation of a developed market infrastructure (production, storage, processing and realization of agricultural products). One of the leading players of agriculture is molokoprodukty subcomplex, in particular dairy cattle. The main aim of branch of dairy cattle breeding is the production in the required amount of milk and dairy products. Features of milk, as a food product due to its chemical composition and properties of the individual components which provide high biological value. Milk is a unique food product that is still not synthesized in the world. In composition it can't compete no one of food products.

Unfortunately, in today's environment, this mission is not entirely performed by most businesses in Lviv region. The problems existing in the industry almost took on a systematic character, whose solution requires a comprehensive approach. The results of our work is to study the nature of development of dairy cattle breeding in the region and identify the reasons hindering the development of the industry.
\end{abstract}

Key words: efficiency, agriculture, dairy cattle, herd of cows, cow productivity, approach of the systems.

\section{Вступ}

Актуальність теми. Молочне скотарство Львівщини потребує розробки цілого комплексу невідкладних заходів щодо підвищення ефективності. Кризова ситуація, що склалася в галузі, змушує констатувати той факт, що більшість господарських формувань, особливо сільськогосподарські підприємства, не в змозі самостійно подолати існуюче коло проблем які набули системного характеру. В даних процесах необхідна, в першу чергу, вагома підтримка державних органів управління та результативний двосторонній діалог із господарськими формуваннями Львівщини. Проте, як свідчить досвід, (при зростанні бюджетних інвестицій селу за 6 останніх років у 3,2 рази, обсяги сільськогосподарського виробництва збільшились в 1,2 рази) (Butko et al., 2007). Це, безумовно вказує на те, що поряд з існуючими проблемами є ще й такі, які пов'язані із цільовим використанням державних асигнувань у галузь вирішення яких потребує втручання силових структур.

Мета $і$ завдання статті. Метою даної статті є виявлення причин, що привели до кризового стану галу3і. Основну увагу сконцентровано на їх системності та необхідності комплексного підходу до їх вирішення.

\section{Матеріал і методи досліджень}

Дослідженнями розвитку молокопродуктового підкомплексу i, зокрема молочного скотарства займаються багато вчених-аграрників серед яких М.П. Бутко (Butko et al., 2007), І.П. Павлов (Pavlov,
2000), Ю.Я. Лузан (Luzan, 2010), М.В. Рухтурак (Rukhturak, 2015). Більшість зазначених авторів спрямовують основну увагу на дослідженні окремих чинників, які створюють негативні умови для нормального розвитку галузі. Такий підхід унеможливлює простежити їх взаємозалежність між собою та побачити всю їх різноманітність в комплексі. Метою ж нашого дослідження $є$ виявлення найвагоміших причин і застосуванням системного підходу, завдання якого полягає у зниженні впливу негативних факторів.

\section{Результати та їх обговорення}

Відомо, що молочне скотарство в минулому розвивалось стабільними темпами, тим самим забезпечуючи населення продуктами харчування в необхідній кількості, а переробні підприємства сировиною. У сьогоднішніх умовах спостерігається негативна тенденція розвитку молокопродуктового підкомплексу i, зокрема молочного скотарства у Львівській області. Аналіз показників виробництва молока на Львівщині свідчить про те, що за останні роки в області суттєво зменшилися обсяги його виробництва на душу населення.

Так, за рекомендаціями Київського науководослідного інституту гігієни і харчування, норма споживання молока і молочних продуктів на душу населення України в рік становить 390 кг, або одну третину за калорійністю добового раціону. У молоці містяться всі речовини пластичного та енергетичного характеру, необхідні організму людини. За відомим висловом академіка І.П. Павлова, молоко чудово ви- 
діляється серед інших видів продуктів, виготовлених самою природою. Немає іншого повноцінного продукту, який людина одержує у готовому вигляді для безпосереднього вживання (Pavlov, 2000).

Однак, протягом 1990-2014 рр. спостерігається чітка тенденція до зниження виробництва молока в розрахунку на душу населення області. За даний період цей показник скоротився на $39,7 \%$ і складав 237 кг у 2014 році, що в натуральному відношенні становить 156 кг. Це свідчить про те, що не забезпечується норма споживання молока на одну людину, або ця норма виконується завдяки імпортній продукції. Наявна тенденція дає можливість констатувати про те, що в недалекому майбутньому ми споживатимемо в більшій мірі імпортну продукцію.

Важливим показником, що впливає на обсяги виробництва продукції молочного скотарства і характеризує рівень інтенсивності його розвитку є наявність поголів'я великої рогатої худоби (BPX) i, зокрема, корів як одного з основних фондів галузі. Аналізуючи дані таблиці 1 необхідно відмітити, що на протязі 1991-2015 pp. (станом на 1 січня) поголів'я тварин в усіх категоріях господарств Львівщини значно скоротилося. Зменшення складало 80,8\%,, а до 2001 р. $62,8 \%$. Більш критична динаміка намітилася у сільськогосподарських підприємствах. Так, за роки незалежності, кількість ВРХ в них зменшилося в понад 30 разів, а в господарствах населення на 52,6\%. За період 32001 р. по 2015 р. відповідно на 79,9\%; 16,8\%. Абсолютно така ж тенденція спостерігається і в зміні чисельності поголів'я корів. Станом на 1 січня 2015 p. в порівнянні з 1991 р. скорочення становило 66,2\%, а до 2001 р. 59,4\% в усіх категоріях господарств, у тому числі в сільськогосподарських підприємствах зменшення було помітне і складало 95,5\%; 77,0\% відповідно. Значно менші коливання чисельності корів присутні в особистих господарствах населення (2015 р. 41,5\% до 1991 р., і 15,5\% до 2001 р.).

Аналіз структури поголів'я (ВРХ) впродовж 19912015 pр. (станом на 1 січня) свідчить про те, що у всіх категоріях господарюючих суб'єктів частка корів мала тенденцію до збільшення зокрема, найбільша їх питома вага зосереджена в особистих селянських господарствах. Причиною цього є те, що переважна більшість сільських господарів в сьогоднішніх умовах вимушені тримати більше корів у своїй господарці для виживання та власного споживання молока і молочних продуктів. Проте, 3 кожним роком, даний показник зменшується. Це пов'язано в основному із переїздом сільських жителів (молоде покоління) у міста та за кордон i, як наслідок, старе покоління фізично не має можливості доглядати за тваринами, i змушене в більшості випадків реалізовувати їх на забій. Така тенденція веде до руйнування на сьогоднішній момент провідної і стабілізуючої ланки у валовому виробництві молока особистої господарки. Так, для прикладу, за 19902008 роки скорочення абсолютної величини трудового потенціалу сільських територій в цілому по Україні зменшилася на 139,9 тис. осіб, або на 2,1\% (Luzan, 2010).

Враховуючи сказане, на нашу думку, в першу чергу слід задуматись над тим, яким чином можна повернути молоде покоління у село. Адже, в кращому випадку, це забезпечить не тільки нарощування особистої господарки, а й сприятиме розвитку підприємництва у сільській місцевості. Виникає нагальна необхідність щодо розробки чітких конкретних заходів, які б включали формування економічної, соціальної, культурно-побутової інфраструктури на селі, заохочували 6 кожного молодого сільського жителя до ведення підприємницької діяльності, розвитку екотуризму.

Таблиия 1

Поголів'я великої рогатої худоби в різних категоріях господарств (станом на 1 січня), тис. голів

\begin{tabular}{|c|c|c|c|c|c|c|c|c|c|c|}
\hline \multirow[t]{2}{*}{ Показники } & \multicolumn{8}{|c|}{ Роки } & \multicolumn{2}{|c|}{$\begin{array}{c}2015 \text { p у } \% \\
(+;-) \text { до }\end{array}$} \\
\hline & 1991 & 1996 & 2001 & 2011 & 2012 & 2013 & 2014 & 1015 & $1991 \mathrm{p}$. & $2001 \mathrm{p}$. \\
\hline \multicolumn{11}{|c|}{ Усі категорії господарств } \\
\hline $\begin{array}{c}\text { Велика рогата худоба - } \\
\text { всього }\end{array}$ & 1095,4 & 771,1 & 565,7 & 259,1 & 237,6 & 250,5 & 240,4 & 210,3 & $-80,8$ & $-62,8$ \\
\hline в т. ч. корови & 404,7 & 390,6 & 336,9 & 161,7 & 155,9 & 152,4 & 146,6 & 136,7 & $-66,2$ & $-59,4$ \\
\hline $\begin{array}{c}\text { питома вага їх у струк- } \\
\text { турі стада, \% }\end{array}$ & 36,9 & 50,7 & 59,6 & 62,4 & 65,6 & 60,8 & 60,9 & 65,0 & $\mathrm{x}$ & $\mathrm{x}$ \\
\hline \multicolumn{11}{|c|}{ Сільськогосподарські підприємства } \\
\hline $\begin{array}{c}\text { Велика рогата худоба - } \\
\text { всього }\end{array}$ & 695,8 & 397,0 & 103,5 & 24,2 & 24,2 & 25,3 & 22,8 & 20,8 & $-97,0$ & $-79,9$ \\
\hline в т. ч. корови & 185,2 & 119,9 & 36,1 & 9,8 & 9,4 & 9,2 & 9,0 & 8,3 & $-95,5$ & $-77,0$ \\
\hline $\begin{array}{c}\text { питома вага їх у струк- } \\
\text { турі стада, \% }\end{array}$ & 26,6 & 30,2 & 34,9 & 40,5 & 38,8 & 36,4 & 39,5 & 39,9 & $\mathrm{x}$ & $\mathrm{x}$ \\
\hline \multicolumn{11}{|c|}{ Особисті господарства населення } \\
\hline $\begin{array}{c}\text { Велика рогата худоба - } \\
\text { всього }\end{array}$ & 399,6 & 374,1 & 462,2 & 227,7 & 213,4 & 225,2 & 217,6 & 189,5 & $-52,6$ & $-16,8$ \\
\hline в т. ч. корови & 219,5 & 270,7 & 300,8 & 151,9 & 146,5 & 143,2 & 137,6 & 128,4 & $-41,5$ & $-15,5$ \\
\hline $\begin{array}{c}\text { питома вага їх у струк- } \\
\text { турі стада, \% }\end{array}$ & 54,9 & 72,4 & 65,1 & 66,7 & 68,7 & 63,6 & 63,2 & 67,8 & $\mathrm{x}$ & $\mathrm{x}$ \\
\hline
\end{tabular}


Наступне, не менш вагоме місце у структурі валових надоїв молока посідає продуктивність молочного стада. Підвищення продуктивності корів належить до інтенсивних чинників. Однак досягнення значних надоїв молока можливе тільки завдяки правильній та збалансованій годівлі тварин, застосування передових технологій доїння корів, дотримання сучасних вимог утримання.

Низька продуктивність корів у всіх областях Західного регіону, зокрема і на Львівщині, гальмує розвиток галузі, що не дає змогу забезпечити населення на рівні рекомендованих норм такими цінними продуктами харчування, як молоко і молочні продукти (Rukhturak, 2015).
Проведений аналіз продуктивності молочного стада в різних категоріях господарств (табл. 2) свідчить про те, що даний показник характеризується позитивною тенденцією до росту. Так, протягом 19912015 pр. (станом на 1 січня) середній удій молока від однієї корови підвищився на 51,8\% в усіх категоріях господарств зокрема, у господарствах населення на 80,3\%. Проте, в сільськогосподарських підприємствах підвищення було малопомітне 9,2\% (3 3176 кг у 1991 р. до 3469 кг у 2015 р.). Починаючи з 2001 р. по 2015 p. (станом на 1 січня) середньорічна продуктивність тварин у даних господарствах характеризувалась незначним зростанням.

Середній річний удій молока від однісї корови в різних категоріях господарств

Табличя 2 (у розрахунку на поголів'я корів на початок року), кг

\begin{tabular}{|c|c|c|c|c|c|c|c|c|c|c|}
\hline \multirow{2}{*}{ Показники } & \multicolumn{8}{|c|}{ Роки } & \multicolumn{2}{|c|}{2015 р у \% (+;-) до } \\
\hline & 1991 & 1996 & 2001 & 2011 & 2012 & 2013 & 2014 & 1015 & 1991p. & 2001p. \\
\hline \multicolumn{11}{|c|}{ Усі категорії господарств } \\
\hline $\begin{array}{c}\text { Середньорічний удій } \\
\text { молока від однієї коро- } \\
\text { ви } \\
\end{array}$ & 2704 & 2419 & 3132 & 3861 & 3927 & 4009 & 4087 & 4105 & $+51,8$ & $+31,0$ \\
\hline \multicolumn{11}{|c|}{ Сільськогосподарські підприємства } \\
\hline $\begin{array}{c}\text { Середньорічний удій } \\
\text { молока від однієї коро- } \\
\text { ви, кг }\end{array}$ & 3176 & 2065 & 1913 & 2930 & 3202 & 3635 & 3829 & 3469 & $+9,2$ & $+18,4$ \\
\hline \multicolumn{11}{|c|}{ Особисті господарства населення } \\
\hline $\begin{array}{c}\text { Середньорічний удій } \\
\text { молока від однієї коро- } \\
\text { ви, кг }\end{array}$ & 2296 & 2593 & 3273 & 3906 & 3961 & 4026 & 4100 & 4139 & $+80,3$ & $+5,9$ \\
\hline
\end{tabular}

Табличя 3

Виробництво молока всіх видів в різних категоріях господарств Львівщини (станом на 1 січня), тис т

\begin{tabular}{|c|c|c|c|c|c|c|c|c|c|c|}
\hline \multirow[t]{2}{*}{ Показники } & \multicolumn{8}{|c|}{ Роки } & \multicolumn{2}{|c|}{$\begin{array}{c}2014 \text { p у \% } \\
(+;-) \text { до }\end{array}$} \\
\hline & 1991 & 1996 & 2001 & 2011 & 2012 & 2013 & 2014 & 1015 & 1991p. & $2001 p$. \\
\hline \multicolumn{11}{|c|}{ Усі категорії господарств } \\
\hline Вироблено молока & 1083,9 & 961,2 & 1032,0 & 656,2 & 629,6 & 620,7 & 619,4 & 601,0 & $-44,6$ & $-41,8$ \\
\hline $\begin{array}{c}\text { Середні витрати кормів } \\
\text { на виробництво } 1 \text { цент- } \\
\text { нера молока, } \\
\text { ц. к.о. }\end{array}$ & 1,41 & 1,57 & 1,33 & 1,02 & 1,01 & 0,98 & 0,98 & 0,97 & $-31,2$ & $-27,1$ \\
\hline \multicolumn{11}{|c|}{ Сільськогосподарські підприємства } \\
\hline Вироблено молока & 588,1 & 275,4 & 66,0 & 22,9 & 23,1 & 25,7 & 26,4 & 24,9 & $-95,8$ & $-62,3$ \\
\hline $\begin{array}{c}\text { Середні витрати кормів } \\
\text { на виробництво } 1 \text { цент- } \\
\text { нера молока, } \\
\text { ц. к.о. }\end{array}$ & 1,47 & 1,77 & 1,63 & 1,18 & 1,16 & 1,09 & 1,06 & 1,02 & $-30,6$ & $-37,4$ \\
\hline \multicolumn{11}{|c|}{ Особисті господарства населення } \\
\hline Вироблено молока & 495,8 & 685,8 & 966,0 & 633,3 & 606,5 & 595,0 & 593,0 & 576,1 & $+16,2$ & $-40,3$ \\
\hline $\begin{array}{c}\text { Середні витрати кормів } \\
\text { на виробництво } 1 \text { цент- } \\
\text { нера молока, } \\
\text { ц. к.о. }\end{array}$ & 1,23 & 1,32 & 1,21 & 0,98 & 0,97 & 0,95 & 0,95 & 0,95 & $-22,7$ & $-21,5$ \\
\hline
\end{tabular}


Проводячи аналогію за результатами проаналізованих показників можна 3 впевненістю стверджувати про те, що характер їх змін відбувався в чіткій взаємозалежності один від одного. Дослідження підтвердили системність розвитку молочного скотарства де кожен елемент взаємодіє один 3 одним у нерозривному зв'язку i, зміна одного з них - змінює усю систему. Це і штовхнуло нас на думку, що для підвищення ефективності функціонування галузі зокрема, зростання об’ємів виробництва молока, удосконалення існуючих міжгосподарських та міжгалузевих зв'язків, необхідно комплексно підійти до розв'язання усіх проблем, що гальмують ці процеси. А це в свою чергу забезпечить збільшення чисельності тварин та зростання їх продуктивності.

\section{Висновки}

Враховуючи вище сказане слід відмітити, що обсяги виробництва молока однозначно залежать від чисельності поголів'я корів та їхньої продуктивності. Проте, кожен із зазначених показників коливається під впливом різноманітних чинників та факторів, що в тій чи іншій мірі коригують їхню величину. Одні, як правило, сприяють їхньому росту, а інші створюють негативні умови, що практично ведуть до їх скорочення. Однак, середовище, в якому функціонують господарські формування області, в більшій мірі надає їм загрози, а ніж можливості. I, як виявилося, сукупність загроз утворило певне системне оточення, в якому опинилося молочне скотарство. Таке середовище за своєю суттю гальмує розвиток та поволі руйнує молочну галузь. Тому при вирішенні всіх назрілих проблем, що існують в галузі, слід використовувати, на нашу думку, системний підхід. I тільки за наявності програм, які б в комплексі охоплювали всі необхідні заходи, методи та прийоми що забезпечують викорінення причин всіх невдач, можливий вихід 3 кризового стану в якому опинилася галузь.

Перспективи подальших досліджень. Для досягнення мети даної публікації, на майбутнє ми пропонуємо наступну модель реалізації цього завдання.

1. Серед усіх показників, що характеризують розвиток галузі, необхідно вибрати найважливіші.

2. Окреслити коло факторів, що мають найбільший вплив по кожному вибраному показнику.
3. Виявити, які із факторів впливають на два і більше показника. Це унеможливить накладання необхідних ресурсів виділених на їх усунення.

4. В залежності від природи чинників, розробити чіткі заходи, рекомендації, способи та прийоми, що послаблюють або дезактивують їхній вплив на кожен із вибраних показників.

5. Об'єднати всі заходи в одну конкретну Програму, Концепцію.

6. Провести чіткий розрахунок щодо забезпеченості виконання Програми необхідними фінансовими, матеріальними, трудовими технологічними та іншими видами ресурсів.

7. Скласти план-графік реалізації поставленого завдання де зазначити, термін виконання кожного пункту Програми, хто буде виконувати ту чи іншу роботу, скільки і в якій кількості потрібно ресурсів на реалізацію кожної задачі.

8. Визначити міру відповідальності тобто винагороду або покарання кожної особи за виконання чи невиконання поставленої перед нею задачі.

9. Здійснювати поточний і попередній контроль за виконанням Програми у вигляді (звітів, нарад, засідань зборів).

Основною умовою реальності проведення вище зазначених заходів $є$ достовірність, повнота, чіткість та періодичність інформації, яка подаватиметься та відображатиме хід виконання Програми.

\section{Бібліографічні посилання}

Butko, M.P., Zelens'ka, O.O., Zelens'kyy, S.M. (2007). Efektyvnist' derzhavnoyi pidtrymky sil's'koho hospodarstva v Ukrayini: realiyi ta perspektyvy. Visnyk ekonomichnoyi nauky Ukrayiny: naukovyy zhurnal. 2(12), 19-24 (in Ukrainian).

Pavlov, V. (2000). Formuvannya spozhyvchoho rynku v rehioni $\mathrm{V}$ umovakh perekhidnoho periodu. Rehional'na ekonomika. 2 (in Ukrainian).

Luzan, Yu.Ya. (2010). Sotsial'no-trudovyy potentsial ukrayins'koho sela. Ekonomika APK, L'viv. 1, 123-127 (in Ukrainian).

Rukhturak, M.V. (2015). Otsinka rivnya efektyvnosti vyrobnytstva moloka $\mathrm{v}$ sil's'kohospodars'kykh pidpryyemstvakh Zakhidnoho rehionu Ukrayiny. Ekonomika APK. L'viv. 1, 75-78 (in Ukrainian). Стаття надійшла до редакиії 18.09.2016 